\title{
Risk Factors for the Misuse of Psychoactive Substances Among University Students in the Niger Delta Region of Nigeria
}

\author{
Chukwujekwu Chidozie Donald \\ Department of Neuropsychiatry, Faculty of Clinical Sciences, University of Port Harcourt, Port Harcourt, Nigeria
}

Email address:

chidozie.chukwujekwu@uniport.edu.ng

To cite this article:

Chukwujekwu Chidozie Donald. Risk Factors for the Misuse of Psychoactive Substances Among University Students in the Niger Delta Region of Nigeria.American Journal of Psychiatry and Neuroscience. Vol. 5, No. 2, 2017, pp. 26-30. doi: 10.11648/j.ajpn.20170502.14

Received: April 12, 2017; Accepted: April 18, 2017; Published: April 24, 2017

\begin{abstract}
The use of psychoactive substances has dire consequences for the individual and the society at large. This study aims to ascertain the risk factors for the misuse of psychoactive substances among University students in the Niger Delta region of Nigeria. Two hundred and ninety three subjects participated in the study. Questionnaires on risk factors and varieties of psychoactive substances used as well as on socio-demographic variables were administered to each participant.The most commonly used psychoactive substance was Alcohol 178(60.8\%). The commonest reason for using a psychoactive substance was peer group influence $166(56.7 \%)$. Frustration was significantly associated with academic class $\left(\mathrm{X}^{2}=17.358, \mathrm{df}=5\right.$, $\mathrm{p}<0.05)$ and family history of use of the substance $\left(\mathrm{X}^{2}=6.22, \mathrm{df}=1, \mathrm{p}<0.05\right)$. Academic class was also significantly associated with peer group influence $\left(X^{2}=28.914, d f=5, p<0.05\right)$, parental deprivation $\left(X^{2}=20.331, d f=5, p<0.05\right)$, age $\left(X^{2}=25.595\right.$, $\mathrm{df}=18, \mathrm{p}<0.05)$ and influence of parents who engage in the use and abuse of substances $\left(X^{2}=22.057, \mathrm{df}=5, \mathrm{p}<0.05\right)$. Gender was significantly associated with influence of parents who use psychoactive substances $\left(X^{2}=9.305, d f=1, p<0.05\right)$. The multiplicity of significant risk factors for psychoactive substance use underscores the need to improve the social support for students and reduce the environmental factors that make the young and impressionable minds more susceptible to drug use. The urgent need for deliberate drug- demand reduction strategies to be quickly employed in schools is imperative.
\end{abstract}

Keywords: Risk, Psychoactive, Substances, Significant, Association, Drugs, Factors

\section{Introduction}

Psychoactive substances refer to brain-altering substances which may or may not have been medically prescribed but are prone to abuse. These substances affect internally perceived mental states such as mood and externally observed activities such as behaviour. "They include alcohol, opioids, cannabinoids, sedatives and hypnotics, cocaine, other stimulants such as caffeine, hallucinogens, tobacco, volatile solvents etc" [1].

The deleterious impact of these substances in humanity is colossal and incalculable. Aside from the staggering cost to society, the physical and psychological difficulties which they precipitate are well documented [1].

It is estimated that 153 to 300 million people (3.4-66\% of the world population in the age group 15 to 64years)used psychoactive substances at least once in 2010 [2].
WHO estimates that 5.4 million people die annually from tobacco use while 2.5 million people die annually as a result of the harmful use of alcohol [3].

$12.4 \%$ of all deaths worldwide in the year 2000 was attributed to psychoactive substances and $8.9 \%$ of total years life lost is use of the traceable to the use of these substances [3].

A variety of factors which influence the use and misuse of psychoactive substances, have been reported. There include the aging process with its attendant multiple health problems, poor physical health, low socioeconomic status, female gender, co-morbid mental health problems, etc $[4,5,6]$.

Tsefaye et al opined that "the rapid economic, social and cultural transitions that most countries in sub-Saharan Africa are now experiencing have created a favourable condition for increased and socially disruptive use of drugs and alcohol" [7]. 
Nevertheless, none of these studies have been carried out in the Niger Delta region of Nigeria, the unofficial centre of Nigeria's booming oil industry with its attendant elevated violent crime rate and youth restiveness on account of conflict over resource control.

The aim of this study therefore is to explore the risk factors for the use of psychoactive substance among university students in the Niger Delta region of Nigeria. Knowledge of the risk factors will enhance greater understanding of the complex problem of substance abuse. This will enable the development of adequate interventions that will help in the management this global challenge.

The study took place within a 4month period (FebruaryMay 2015). It is important to note that what is presented in this paper, "Risk factors for the misuse of psychoactive substances among university students in Niger Delta, Nigeria" is part of that large study.

\section{Methodology}

This cross sectional study was conducted among undergraduate students at Madonna University Elele in Rivers State. The school has a student population of 5235 students.

\subsection{Instruments: The Instruments Used in the Research Include}

(1) A questionnaire on risk factors and varieties of psychoactive substances abused; designed by the authors. It consists of 2 sections: a section with ten questions aimed at ascertaining the variety of psychoactive substances abused and another section with eight questions meant to elicit the risk factors for the use of the substances.

Subjects were meant to answer "yes" or "no" to the questions. Before the commencement of the study, a pilot study was carried out; the questionnaire was found to have a discriminant validity of $89 \%$.

(2) A questionnaire on socio-demographic variables.

\subsection{Procedure}

Via random sampling, 293 students who consented to the study were enlisted. Before the commencement of the study, a verbal consent was sought from the respondents and they were assured of confidentiality as their names were not included in the questionnaire. The students selected, completed the questionnaire during class hours after adequate explanation of what the study was all about and how to fill the questionnaire had been done. The data collection took place for four months (February-May 2015).

\subsection{Analysis}

The data was analyzed using the Statistical Package of the Social Sciences (SPSS) version 15. Statistical methods applied were frequency counts and tables as well as tests for association (chi-square test for categories variables and students $\mathrm{t}$ test for continuous variables).

\section{Results}

Two hundred and ninety three subjects participated in this study. The mean age of the subjects was $23.89 \pm 3.148$ years and the cohort comprises 166males (56.7\%) and 127 females $(43.3 \%)$.

The most commonly used psychoactive substance used was alcohol 178(60.8\%), while the least used substance was inhalational solvents $75(25.6 \%)$. See table 2 .

The commonest reason for using psychoactive substances was "peer group influence" 166(56.7\%). The least common risk factor to use of these substances was "parental deprivation" 97(33.1\%). See table 3 .

Table 4 shows the association between risk factors for abusing these substances and socio demographic variables.

The risk factor "frustration" is significantly associated with gender $X^{2}=9.614, \mathrm{df}=1, \mathrm{p}<0.05$, (the higher the class the more the frustration) as well as with the family history of use of psychoactive substances $\mathrm{X}^{2}=6.221, \mathrm{df}=1, \mathrm{p}<0.05$.

Low self esteem is not significantly associated with any socio-demographic variables.

Pear group influence is significantly associated with academic class. $\mathrm{X}^{2}=28.914, \quad \mathrm{df}=5, \mathrm{p}<0.05$. Parental deprivation is significantly associated with academic class $\mathrm{X}^{2}=20.331, \mathrm{df}=5, \mathrm{p}<0.05$.

Drug abuse for fun and relaxation is significantly associated with age $\mathrm{X}^{2}=25.595, \mathrm{df}=18, \mathrm{p}<0.05$ and academic class $X^{2}=36.405, \mathrm{df}=5, \mathrm{p}<0.05$.

Social influence due to the proximity where substance are sold or brewed is significantly associated with academic class. There is no significant association between ready availability of psychoactive substance and sociodemographic variables.

Table 1. Demographic and clinical characteristics of the respondents.

\begin{tabular}{lll}
\hline VARIABLE & FREQUENCY & (\%) \\
\hline Age $($ yrs $)$ & & \\
$\leq 20$ & 18 & $(6.1)$ \\
$21-30$ & 262 & $(89.4)$ \\
$31-40$ & 12 & $(4.1)$ \\
$>40$ & 1 & $(0.3)$ \\
Mean age $=23.89 \pm 3.148$ yrs & & \\
Gender & & \\
Male & 166 & $(56.7)$ \\
Female & 127 & $(43.3)$ \\
Year of study & & \\
Year 1 & 32 & $(10.9)$ \\
2 & 46 & $(15.7)$ \\
3 & 44 & $(15.0)$ \\
4 & 85 & $(29.0)$ \\
5 & 73 & $(24.9)$ \\
6 & 12 & $(4.1)$ \\
Family history of use psychoactive substances & & $(18.4)$ \\
Positive family history & 54 & $(81.6)$ \\
Negative family history & 239 & \\
\hline
\end{tabular}


Table 2. Proportions of rate of use of psychoactive substances.

\begin{tabular}{lll}
\hline PSYCHOACTIVE SUBSTANCES & YES (\%) & NO (\%) \\
\hline Alcohol & $178(60.8)$ & $115(39.2)$ \\
Cannabis & $112(38.2)$ & $181(61.8)$ \\
Cocaine & $113(38.6)$ & $180(61.4)$ \\
Heroine & $107(36.5)$ & $186(63.5)$ \\
Codeine & $141(48.1)$ & $152(51.9)$ \\
Opioids & $91(31.1)$ & $202(68.9)$ \\
Sleeping pills & $129(44.0)$ & $164(56.0)$ \\
Nicotine & $128(43.7)$ & $165(56.3)$ \\
Caffeine & $168(57.3)$ & $125(42.7)$ \\
Inhalational solvents & $75(25.6)$ & $218(74.4)$ \\
\hline
\end{tabular}

Table 3. Frequency of risk factors for use of psychoactive substances.

\begin{tabular}{lll}
\hline RISK FACTOR & YES (\%) & NO(\%) \\
\hline Frustration & $148(50.5)$ & $145(49.5)$ \\
Low self esteem & $132(45.1)$ & $161(54.9)$ \\
Peer group influence & $166(56.7)$ & $127(43.3)$ \\
Parental deprivation & $97(33.1)$ & $196(66.9)$ \\
Drug abuse for fun and relaxation & $153(52.2)$ & $140(47.8)$ \\
Influence of parents who engage in the & $117(39.9)$ & $176(60.1)$ \\
$\quad$ use and abuse of substance & $135(46.1)$ & $158(53.9)$ \\
Social influence due to proximity where it is sold or brewed & & $163(55.6)$ \\
Readily available & $130(44.4)$ & \\
\hline
\end{tabular}

Based on odd ratios above, the risk factor which leads respondents to indulge in the use psychoactive substance is peer group influence $166(56.7 \%)$.

The least probable risk factor for use of psychoactive substances is parental deprivation $97(33.1 \%)$

Table 4. Association between risk factors for abusing substances and Socio demographic variables.

\begin{tabular}{|c|c|c|c|c|c|c|c|c|}
\hline & $\begin{array}{l}\text { Frustratio } \\
\text { nX2, df } \\
\text { (p value) }\end{array}$ & $\begin{array}{l}\text { Low self } \\
\text { esteem }\end{array}$ & $\begin{array}{l}\text { Peer } \\
\text { group } \\
\text { influence }\end{array}$ & $\begin{array}{l}\text { Parental } \\
\text { deprivation }\end{array}$ & $\begin{array}{l}\text { Drug abuse } \\
\text { for fun and } \\
\text { relaxation }\end{array}$ & $\begin{array}{l}\text { Influence of parents } \\
\text { who engage in the use } \\
\text { and abuse of substance }\end{array}$ & $\begin{array}{l}\text { Social influence due } \\
\text { to proximity where it } \\
\text { is sold or brewed }\end{array}$ & $\begin{array}{l}\text { Readily } \\
\text { available }\end{array}$ \\
\hline \multicolumn{9}{|l|}{$\begin{array}{l}\text { Socio Demographic } \\
\text { VARIABLES }\end{array}$} \\
\hline Age & $\begin{array}{l}16.138,18 \\
(0.583)\end{array}$ & $\begin{array}{l}20.922,18 \\
(0.583)\end{array}$ & $\begin{array}{l}17.718,18 \\
(0.474)\end{array}$ & $\begin{array}{l}10.652,18 \\
(0.91)\end{array}$ & $\begin{array}{l}25.595,18 \\
(0.019)\end{array}$ & $\begin{array}{l}18.558,18 \\
(0.420)\end{array}$ & $\begin{array}{l}23.661,18 \\
(0.166)\end{array}$ & $\begin{array}{l}10.842,18 \\
(0.901)\end{array}$ \\
\hline $\begin{array}{l}\text { Gender } \\
\text { (Male/Female) }\end{array}$ & $\begin{array}{l}9.614,1 \\
(0.002)\end{array}$ & $\begin{array}{l}9.805,1 \\
(0.002)\end{array}$ & $\begin{array}{l}0.493,1 \\
(0.552)\end{array}$ & $\begin{array}{l}3.114,1 \\
(0.081)\end{array}$ & $\begin{array}{l}0.299,1 \\
(0.637)\end{array}$ & $\begin{array}{l}9.365,1 \\
(0.003)\end{array}$ & $\begin{array}{l}2.375,1 \\
(0.123)\end{array}$ & $\begin{array}{l}0.631,1 \\
(0.427)\end{array}$ \\
\hline $\begin{array}{l}\text { Academic class } \\
(\text { Yr } 1,2,3,4,5,6)\end{array}$ & $\begin{array}{l}17.358,5 \\
(0.004)\end{array}$ & $\begin{array}{l}10.037,5 \\
(0.074)\end{array}$ & $\begin{array}{l}28.914,5 \\
(0.000)\end{array}$ & $\begin{array}{l}20.331,5 \\
(0.001)\end{array}$ & $\begin{array}{l}36.405,5 \\
(0.00)\end{array}$ & $\begin{array}{l}22.057,5 \\
(0.001)\end{array}$ & $\begin{array}{l}29.211,5 \\
(0.000)\end{array}$ & $\begin{array}{l}9.667,5 \\
(0.085)\end{array}$ \\
\hline $\begin{array}{l}\text { Family History - } \\
\text { Yes/No }\end{array}$ & $\begin{array}{l}6.221,1 \\
(0.016)\end{array}$ & $\begin{array}{l}162,1 \\
(0.763)\end{array}$ & $\begin{array}{l}0.622,1 \\
(0.450)\end{array}$ & $3.541,1$ & $\begin{array}{l}0.004,1 \\
(0.98)\end{array}$ & $\begin{array}{l}5.414,1 \\
(0.02)\end{array}$ & $\begin{array}{l}2.176,1 \\
(0.140)\end{array}$ & $\begin{array}{l}0.383,1 \\
(0.538)\end{array}$ \\
\hline
\end{tabular}

\section{Discussion}

This study revealed that the most commonly used psychoactive substance is alcohol. This is in consonance with several other studies done previously $[89,10]$.

While a study carried out by Daly Jov et al opined that Caffeine is the most widely used psychoactive substance globally [11], another maintained that Cannabis was the most commonly abused among young people [12]. In the Niger Delta region of Nigeria, where this study took place, alcohol is present during all major life transition beginning from birth to death.The birth of a baby is an occasion for celebration with a generous supply of alcohol, conflicts are resolved over a drink, traditional prayers are made with a sprinkle of alcohol on the ground, marriages and other contractual arrangements cannot be sealed without the sharing of a drink, and burial ceremonies are occasions for drinking and revelry [13].

The commonest risk factor identified in this study for the use of psychoactive substances was "peer group influence". This report is in consonance with findings from other studies $[13,14,15]$.

The risk factor, "frustration" is significantly associated with academic class. This is not surprising because, the higher the academic class, the more the pressure, demand and stress associated with rigors of academics. The resultant abuse of psychoactive substances is a maladaptive coping mechanism by those who are vulnerable $[16,17]$. 
It was also discovered that drug use and misuse for fun and relaxation was significantly associated with age. Odejide et al noted that students were initiated into drug use in their early childhood and that "adolescents and young adults now form the risk groups in the abuse of alcohol" [18]. The situation in the Niger Delta region of Nigeria is even more problematic. This is because the region has been embroiled in crisis for the past two decades because of conflict over the control of oil. This has led to violence and crime of increasing propensities and most of these vices have been associated with psychoactive substance abuse $[19,20]$.

Influence of parents was significantly associated with gender. The greater tendency for males to abuse psychoactive substances have been previously documented especially where there is a family history of psychoactive substance abuse [21, 22].

This can be explained by Bandura's social learning theory which posits that people learn from one another via observation, imitation and modeling [23].

\section{Limitations}

This is a cross sectional study. Hence the application of its findings to the general population should be done with caution. More longitudinal studies using larger sample size is recommended.

\section{Conclusion}

The multiplicity of significant risk factors for psychoactive substance use underscores the need to improve the social support for students and reduce the environmental factors that make young and impressionable minds susceptible to drug use.

The urgent need for deliberate drug-demand reduction strategies to be quickly employed in schools is imperative.

\section{References}

[1] Kaplan H.S., Sadock B.J. (2003). Substance - Related Disorders: In Synopsis of Psychiatry, $8^{\text {th }}$ Edn., Williams \& Wilkins (New York) 2003; 375- 455

[2] United Nations Office on Drugs and Crime (Internet). World Drug report 2012 (cited 2013 June 26). http://www.unodc.org/documents/data-andanalysis/WDR2012/WDR2012websmall-pdf(links)

[3] World Health Organization, World Health Statistics (Internet). 2008 (cited 2013 Jan).

http://www.who.int/whr/2006/whr06en.pdf(links).

[4] Beman DS. Risk factors leading to adolescent substance abuse. Adolescence, Roselyn heights 1995; 30 (117).

[5] Okpataku CI, Kwanashie HO, Ejiofor JF, Olisah VO. Prevalence and socio demographic risk factors associated with psychoactive substance use in psychiatric out-patinets of a tertiary hospital in Nigeria. Nigeria Med 2014; 55: 460-464

[6] Kaminerr Y. Psychoactive substance abuse and dependence as a risk factor in adolescent - attempted and completed suicide. The American Journal of Addictions. 1992: Doi

\subsection{1/j.1521-0391.1992.tb00003.x}

[7] Tsefaye G; Derese A, Hambisa MT, Substance Use and Associated Factors among University students in Ethiopia: A cross-sectional study. Journal of Addiction 2014. Article ID 969837, 8pages. http://dx.doi.org/10.1155/2014/969837.

[8] Vieira DL, Ribeiro M. Romano M, Laranjeira RR. Alcohol and adolescents: study to implement municipal policies. Rev. Saude Publica 2007; 41: 396-403.

[9] Secretaria Nacional de Politicas Sobre Drogas (Internet). Relatoriobrasilerosobredrogas. 2009 (cited 2013 Jun 16). http://www.obid.senad.gov.br/portais/OBID/biblioteca/docum entos/relatorios/328370. pdf

[10] Plant M. European School Survey Project on Alcohol and other Drugs (ESPAD Internet) 2007 (cited 2013 Jun 28). http:/www2.uwe.ac.uk/services/marketing/research.pdf/ISHEp dfs/Health17.pdf

[11] Daly TW, Holmen J, Fredholm BB Is Caffeine addictive? The most widely used psychoactive substances in the world affects same parts of the brain as cocaine, Lakartidingen 1998, 95: 51-52.

[12] Boys A, Marsden J, Strang J. Understanding reasons for drug use amongst young people; a functional perspective. Health Edu Res 2001; 16(4): 457-469.

[13] Obot IS. The epidemiology of tobacco and alcohol abuse in Nigeria. in: Obot I.S. (ed). Epidemiology and control of substance abuse in Nigeria. Jos: centre for Research and information on substance abuse. 1993: 432-438.

[14] Chukwujekwu DC, Stanley HO, Chu JC, Frank-Briggs A. The prevalence of drug abuse among secondary school students in Eleme, a sub-urban area of Rivers State, Nigeria. Journal of child language and communication disorders in Nigeria 2008; 1(2): $32-42$.

[15] Ifabumuyi O, Ahmed MH. A Survey of alcoholism of out patients in Kaduna. Nigerian Journal of Psychiatry 1987; 1: 45-49.

[16] Thompson RJ, Mata J, Jaeggi SM, Buschkuchi M, Jonides J, Gotib IH. Maladaptive Coping, Adaptive Coping and Depressive Symptoms: Variations of cross age and depressive State. Behave Res Ther. 2010; 48(6): 459-466.

[17] Brown GQ, Harris GK, Manual for the Beck Depression Inventory - II. Psychological corporation; San Antonio, TX: 1996.

[18] Odejide AO, Ohaeri JU, Adelekan M, Ikuesann BA. Alcohol Treatment system in Nigeria. alcohol and Alcoholism 1989; $24 ; 347-353$.

[19] Stanley PC (ed). Alcohol: A silent Killer. Port Harcourt University of Port Harcourt Press - 2003: 1-68.

[20] Brisbe S, Ordinioha B, Dienye PO. Intersection between alcohol abuse and intimcile partners violence in a rural Ijaw community in Bayelsa State, South-South. Journal of Interpersonal Violence. Doi: 10.1177/088626051

[21] Substance Abuse and mental Health services administration (SAMHSA). Results from the 2013 National Survey on Drug Use and health: summary of National findings. Rockville; MD; substance Abuse and mental Health services administration 2014. HHS Publication No. (SMA) 14-4863. NSDUH services H-48. 
[22] Piper ME, Cook JW, Schlam TR. Gender, race and education differences in abstinence rates among participants in two randomized smoking cessation trials Nicotine Tob Res. 2010; 12(6): 647-657.
[23] Thyer BA, Myers L. Social learning theory: An empirically based approach to understanding human behaviour in the social environment. Journal of Human Behaviour in the social environment 1998; 1:33-52. 